\title{
Investigation of the Use of Collagen-Gelatin-Gold Nanoparticle Nanocomposite System as an Aptasensor Matrix
}

\author{
Kollajen-Jelatin-Altın Nanopartikül Nanokompozit Sisteminin \\ Apta-Sensör Matriksi Olarak Kullanılma Potansiyelinin \\ incelenmesi
}

\author{
Research Article
}

Mehmet Sait Yılmaz', Burak Derkuş²*, Emel Emregül'

${ }^{1}$ Ankara Üniversitesi, Fen Fakültesi, Kimya Bölümü, Ankara, Türkiye.

${ }^{2}$ Eskişehir Osmangazi Üniversitesi, Mühendislik Fakültesi, Biyomedikal Mühendisliği Bölümü, Eskişehir, Türkiye.

\section{A B S TRACT}

\begin{abstract}
n this study, a collagen-gelatin-gold nanoparticles (AuNPs) matrix, a material widely used in biosensor applications, controlled release systems, tissue engineering and many other biotechnology fields, was applied to the apta-sensor technology. The matrix was characterized using techniques like scanning electron microscopy (SEM), thermal gravimetric analysis (TGA) and fourier-transform infrared spectroscopy (FTIR). Immobilization conditions were optimized through immobilization of thrombin binding aptamers (TBA) on to the collagen-gelatin-AuNPs surface. Polymer, cross-linker, AuNPs and aptamer concentrations in addition to $\mathrm{pH}$ were optimized in the developed aptasensor systems. In addition, re-usability and reproducibility were examined for validation purposes. Thrombin levels as low as $1.97 \mathrm{nM}$ were detected using screen printed carbon electrodes as transducer and Electrochemical Impedance Spectroscopy (EIS) as the electrochemical method.
\end{abstract}

\section{Key Words}

Collagen, gelatin, gold nanoparticles, thrombin, impedance, apta-sensor.

\section{öz}

u çalışmada biyosensör, kontrollü salım, doku mühendisliği ve diğer pek çok biyoteknoloji alanında yaygın olarak kullanılan kollajen'in, jelatin ve altın nanopartikül (AuNPs) ile oluşturduğu matriksin taramalı elektron mikroskobu (SEM), termal gravimetrik analiz (TGA), fourier-dönüşümlü infrared spektroskopisi (FTIR) gibi tekniklerle karakterizasyonu ve apta-sensör teknolojisinde kullanımı amaçlanmıştır. Kollajen-Jelatin-AuNPs yüzeyi üzerine trombin bağlayıcı aptamer (TBA) immobilize edilerek immobilizasyon şartları optimize edilmiştir. Geliştirilen apta-sensör sisteminde polimer miktarları, çapraz bağlayıcı, AuNPs miktarı, aptamer konsantrasyonları ve pH optimizasyonu yapılmıştır. Ayrıca validasyon amacıyla tekrar kullanılabilirlik ve tekrar üretilebilirlik parametreleri incelenmiştir. İletici olarak perde-baskı elektrodların ve elektrokimyasal yöntem olarak elektrokimyasal impedans spektroskopisi (EIS)'nin kullanıldığı çalışmada geliştirilen apta-sensör ile 1.95 nM seviyesinde trombin tayini yapılabilmiştir.

\section{Anahtar Kelimeler}

Kollajen, jelatin, altın nanopartikül, trombin, impedans, apta-sensör.

Article History: Received: Apr 18, 2018; Revised: May 5, 2018; Accepted: Jul 6, 2018; Available Online: Nov 13, 2018.

DOI: $10.15671 /$ HJBC. 2018.260

Correspondence to: B. Derkuş, Eskişehir Osmangazi Üni., Mühendislik Fak., Biyomedikal Mühendisliği Bölümü, Eskişehir, Türkiye. 


\section{INTRODUCTION}

Biosensors are small sensing devices used to control target analytes in biological reactions. The task of the biochemical part is to recognize the target molecule by interacting with the substance to be analyzed. As a result of this recognition, a biochemical product can also be formed. The second part of the biosensor, the electrochemical part, is responsible for translating this recognition phenomenon into a readable numerical value $[1,2]$. Selectivity, useful life, reproducibility, stability, high sensitivity, adequate detection limit, fast response time, simplicity and low cost are the characteristics of an ideal biosensor [3]. Biosensors have different types, such as DNA sensors designed to recognize a specific DNA fragment [47], enzymatic sensors prepared by immobilization of enzymes [8,9], or immunosensors based on antigen/antibody interaction [10-12].

The widely used collagen for the biosensor matrix has the advantages of being natural, biocompatible, non-toxic and is the most widely used bio-polymer in biomedical fields thanks to its presence in the matrix of the extracellular matrix. Another biopolymer used in this study is the gelatine as an apta-sensor matrix component. It is formed as a result of the partial hydrolysis of tissues such as gelatin, bone, tendon and some organs and rapidly transforms into a solid-gel form in the presence of crosslinker. The functional groups such as amines, carboxyls and hydroxyls present in the body allow the biological structures to be chemically bound to themselves. Gold nanoparticles are widely used in recent years, especially in sensor and cancer treatment fields, due to their low cost, high stability exhibits and their biocompatibility. The ability to bind thiol groups selectively and without requiring any chemical reactivity has made gold nano-structures particularly important in DNA studies. In this study, it was also preferred to use gold nanoparticles so that the thiol-modified aptamers could be efficiently bound to the sensor matrix.

The apta-sensor developed in this study is aimed to determine the level of thrombin. Thrombin is a protease produced in the blood clotting process and is the only factor that divides fibrinogen for fibrin clot formation. It was known that thrombin was only involved in blood coagulation processes such as hemorrhage and thrombosis in the past, and caused excess or lack of blood clotting diseases. Studies conducted in recent years show that the level of thrombin in the metabolism is not only related to hemorrhage or thrombosis; have also been associated with neuroinflammatory and neurodegenerative diseases such as Alzheimer's, autoimmune encephalomyelitis, acute focal ischemia [13-15]. In this respect, systems to improve the accuracy, precision, practicality and economics of thrombin in the clinic are important.

\section{MATERIALS and METHODS Materials and Apparatus}

Type I collagen, gelatin, gold nanoparticle suspension, glutaraldehyde, thrombin, potassium hexacyanoferrate $\quad\left(\mathrm{K}_{4}\left[\mathrm{Fe}(\mathrm{CN})_{6}\right]\right)$ /potassium ferricyanide $\left(\mathrm{K}_{3}\left[\mathrm{Fe}(\mathrm{CN})_{6}\right]\right)$ redox couple, potassium chloride $(\mathrm{KCl})$ used in the study were obtained from Sigma-Aldrich. Electrochemical measurements were performed using a Gamry Potentiostat/Galvanostat. A Shimadzu DTA60 and a Shimadzu IRAffinity-1 were used for the thermal gravimetric measurements FTIR analysis respectively. SEM images were obtained on a Quanta 400F field emission electron microscope.

\section{Physical and Chemical Characterization of Sensor Matrix}

FTIR, TGA and SEM studies were carried out for the physical and chemical characterization of the sensor matrix. Collagen-gelatin, cross-linked collagen-gelatin, collagen-gelatin containing AuNPs and aptamer immobilized collagen-gelatin materials were prepared and the IR spectra were obtained. TGA analysis was performed with the aim of understanding the effect of gold nanoparticles on the thermal resistance of collagen-gelatin films. For this purpose, $10-12 \mathrm{mg}$ of the samples were primarily heated under nitrogen atmosphere upto $600^{\circ} \mathrm{C}$, followed by $800^{\circ} \mathrm{C}$ under oxygen atmosphere at a heating rate of $10^{\circ} \mathrm{C} / \mathrm{min}$ and overall mass change was observed. SEM images were obtained in order to get a visual understanding of the surface used as the sensor matrix. For SEM analysis, collagen-gelatin, collagen-gelatin-AuNPs and TBA immobilized structures were modified onto a carbon surface coated with a $\mathrm{Pd} / \mathrm{Au}$ coating and examined under electron microscope. 


\section{Apta-sensor Design}

A screen-printed carbon electrode is used as the transducer in the development of the apta-sensor system. In the preparation of the electrodes, gelatin and collagen were first mixed in a microtube, whereafter AuNPs were added to the mixture to obtain a nano-biocomposite structure. This was followed by the addition of glutaraldehyde into the mixture, as the crosslinking agent. $10 \mu \mathrm{L}$ of this mixture was then modified to the surface of the screen-printed carbon electrode and allowed to dry for 2 hours. TBA was added to the nanocomposite surface after the surface was washed for 15 minutes using phosphate buffer, resulting in the formation of a AuNPs-Thiol-TBA surface structure. After washing 3 times with phosphate buffer for 15 min to remove any unbound TBA molecules, thrombin was added to the surface at the desired concentration. Electrochemical measurements were obtained following an incubation period of 30 minutes ensuring the aptamer-thrombin interaction. Electrochemical measurements were performed in a $1 \mathrm{~mL}$ screen-printed electrode cell containing $0.1 \mathrm{M} \mathrm{KCl}, 5 \mathrm{mM} \mathrm{K}_{3}\left[\mathrm{Fe}(\mathrm{CN})_{6}\right] / \mathrm{K}_{4}\left[\mathrm{Fe}(\mathrm{CN})_{6}\right]$ and 0.05 $\mathrm{M}$ phosphate buffer as the electrolyte medium.

The collagen/gelatin ratio, glutaraldehyde crosslinker concentration, AuNPs concentration, TBA concentration and thrombin incubation time were optimized sequentially by preparing matrices in the following concentration ranges or ratios; collagen/gelatin ratio between 1:20 to 20:1, glutaraldehyde concentration between 0.001 to $0.005 \mathrm{M}$, AuNPs concentration between 0.5 to $4 \mu \mathrm{L}\left(2.25 \times 10^{10}-2.0 \times 10^{12}\right.$ particles $)$, TBA concentration between 3-15 $\mu \mathrm{M}$. The thrombin incubation time was varied between 10-90 min. Reproducibility and reusability studies were also performed for validation of the developed aptasensor. Reproducibility was evaluated through the electrochemical measurement of 10 electrodes prepared using optimum collagen-gelatin-AuNPs, cross-linker and aptamer concentrations at a constant thrombin concentration of $1 \mu \mathrm{L}$ and constant incubation time. In the reusability study, the electrode was immersed in the amino acetic acid buffer for 1 day at $+4^{\circ} \mathrm{C}$ after the $1^{\text {st }}$ day measurement with the prepared apta-sensor, and the binded thrombin was removed from the surface. This process was repeated for 14 days. Finally, measurements were taken with thrombin incubation at different concentrations (1.95-1000 nM) for calibration studies and a calibration graph was obtained. All experiments were repeated 3 times.

\section{RESULTS and DISCUSSION Physical and Chemical Characterization}

Figure 1 shows the IR spectrum of the collagengelatin system.

$\mathrm{N}-\mathrm{H}$ stretching of the amide band at around $3290 \mathrm{~cm}^{-1}$ from the common peaks of collagen

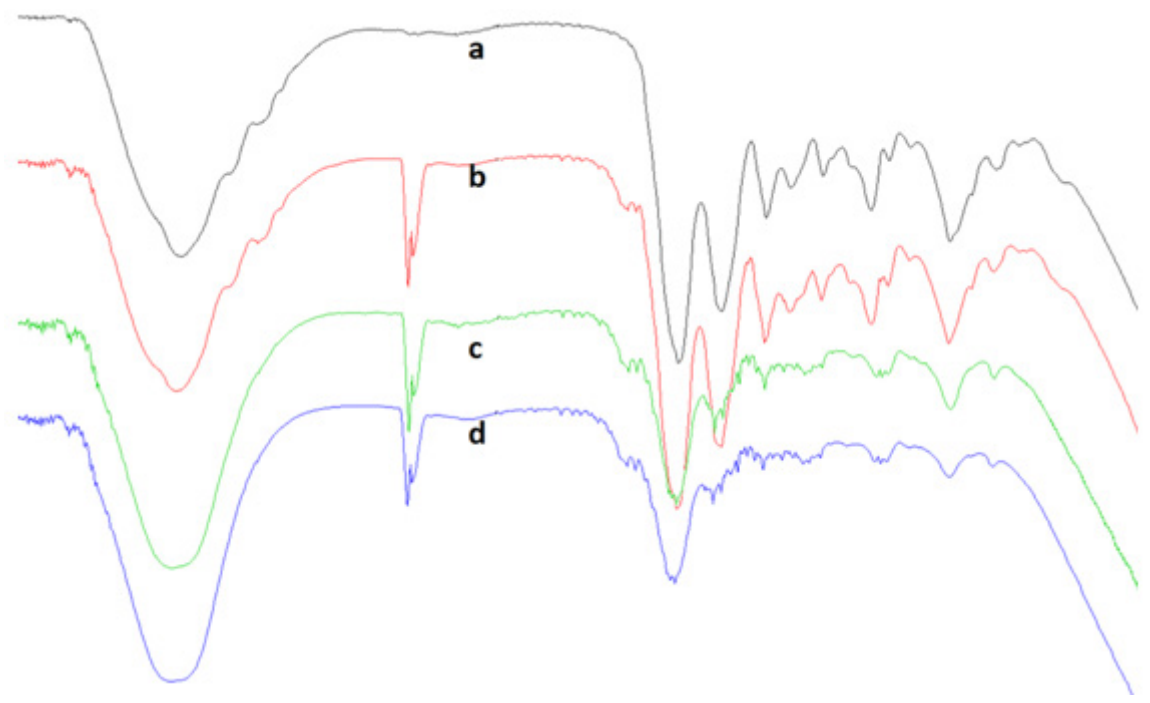

Figure 1. FTIR spectrum of collagen-gelatin (a), cross-linked collagen-gelatin (b), cross-linked collagen-gelatin-AuNPs (c) and cross-linked collagen-gelatin-AuNPs-TBA (d) electrodes. 
and gelatin in the spectrum can be easily seen (a). The amide band associated with assymetrical $\mathrm{CH}_{2}$ stretching is observed at $2920 \mathrm{~cm}^{-1}$ (b). This is in general associated with the secondary structure of the amide I band observed between 1600-1700 $\mathrm{cm}^{-1}$. The vibration band of the carbonyl group of the polypeptide membrane was observed at 1640$1650 \mathrm{~cm}^{-1}$. The bands at 1230 and $140 \mathrm{~cm}^{-1}$ belong to the amide III vibration and are evidence of the presence of a helix structure. A remarkable point in the spectrum of collagen and gelatin cross-linked with glutaraldehyde $(b)$ is the reduction of vibrations of free amine groups; amide I vibration. This is due to the amide bond formation of the amine and carboxyl groups of collagen and gelatin through cross-linking, indicating the success of crosslinking. When gold nanoparticles are included in the system, the peak intensity at $3420 \mathrm{~cm}^{-1}$ appears to increase (c). This is due to the bonding of the gold ions with hydroxyl oxygens. Finally, the spectrum shown in (d) was obtained when the aptamers were included in the composite structure containing gold nanoparticles, due to the formation of disulfide bonds. This spectrum has similar properties to the
collagen-gelatin-AuNPs spectrum and no damage has occurred to the structure.

Figure 2 shows the thermal analysis spectra of collagen-gelatin and collagen-gelatin-AuNPs nanocomposite materials. When the TGA spectrum of the collagen-gelatin composite is examined, a two-step thermal degradation is seen. It is widely known that thermal degradation below $150{ }^{\circ} \mathrm{C}$ is due to water loss. There is a loss of about $25 \%$ in collagen caused by moisture. The second disruption site between $200-400^{\circ} \mathrm{C}$ is related to the disruption of peptide bonds and the degradation of proteins. When gold nanoparticles were added to the collagen-gelatin structure, an increase in the thermal stability was observed. With a two-step thermal fragmentation, only about $30 \%$ of this material is degraded, and gold nanoparticles have been shown to increase the structural durability.

In Figure 3, SEM images of collagen-gelatin, collagen-gelatin-AuNPs and collagen-gelatin-AuNPsaptamer modified electrodes are shown. The morphology of the film of the $2 \mathrm{D}$ collagen-gelatin

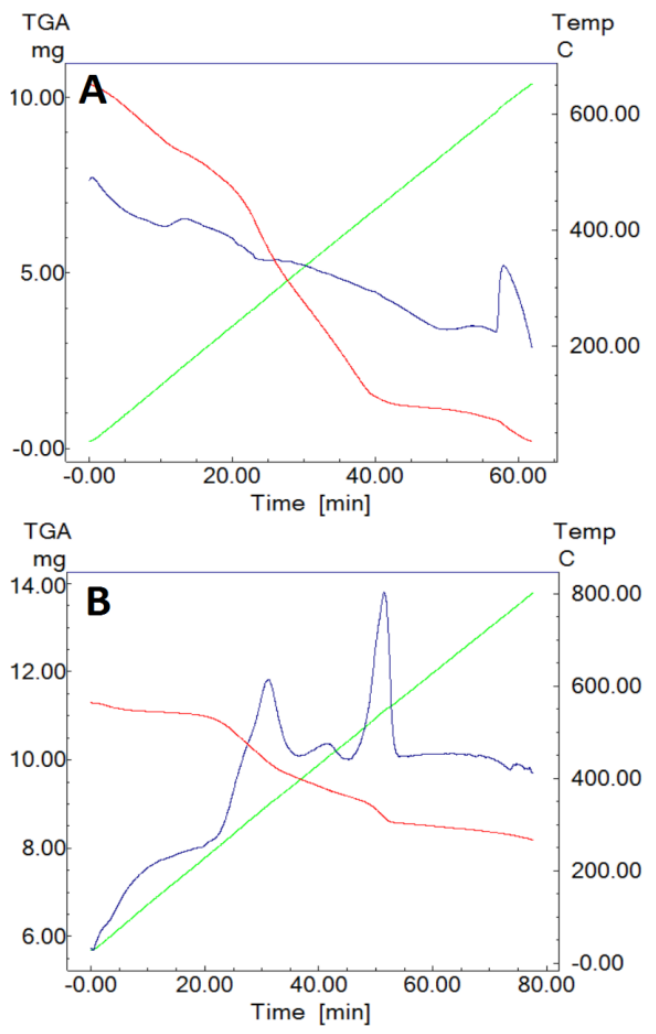

Figure 2. TGA spectrum of collagen-gelatin (A), collagen-gelatin-AuNPs (B) materials. 


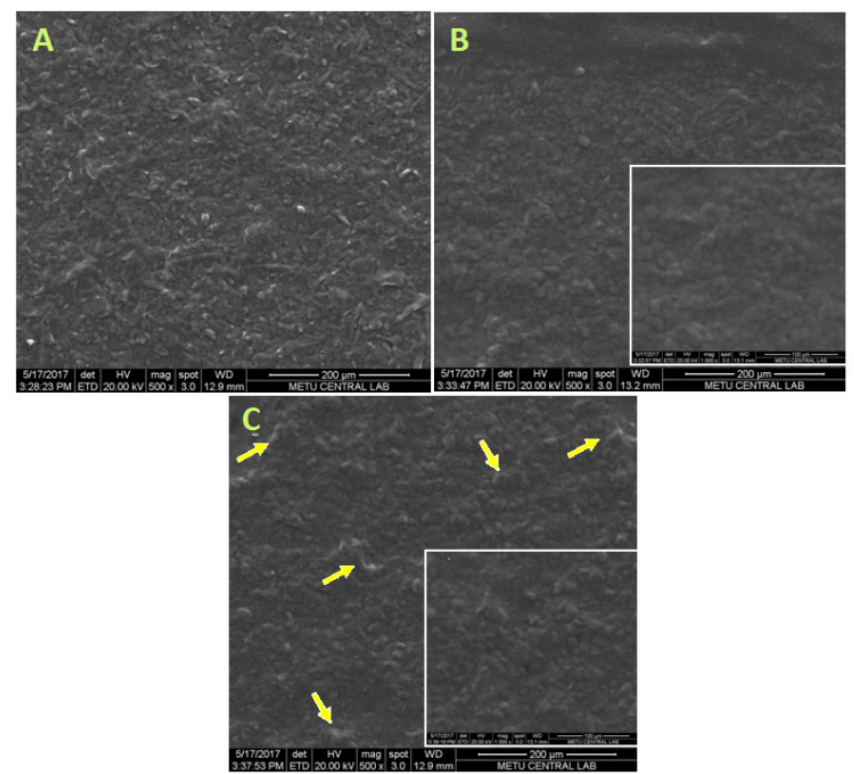

Figure 3. SEM images of collagen-gelatin (A), collagen-gelatin-AuNPs (B), collagen-gelatin-AuNPs-TBA (C) modified electrodes.

structure is shown in Figure 3A. The developed biomolecule completely covers the electrode surface and does not allow direct electron transfer. This is a suitable matrix for use in electrochemical biosensor technology. When gold nanoparticles in nanoscale dimensions are incorporated into this system (Figure $3 \mathrm{~B}$ ), the material surface becomes more porous. The porous structure is important in sensor technology as it enables or enhances electron transfer from the unit side and increases the efficiency of aptamer immobilization. In Figure 3C, the success of aptamer immobilization can physically be seen. As a result, the thrombin binding aptamers are successfully attached to the sensor nanocomposite matrix.
Optimization studies revealed an optimum polymer ratio of 10:1 collagen-gelatin, crosslinker concentration of $0.003 \mathrm{M}$, nanoparticle amount of $2.0 \mu \mathrm{L}$ and aptamer concentration of $10 \mu \mathrm{M}$ for a thrombin apta-sensor with a maximum efficiency (Figure 4). A lower crosslinker concentration leads to the formation of a polymeric surface structure with low mechanical strength whereas if it exceeds the optimum concentration it leads to the formation of compact structure inhibiting electron transfer. Gold nanoparticles increase the amount of surface area and electron transfer by a certain amount while the high amounts of the gold nanoparticles
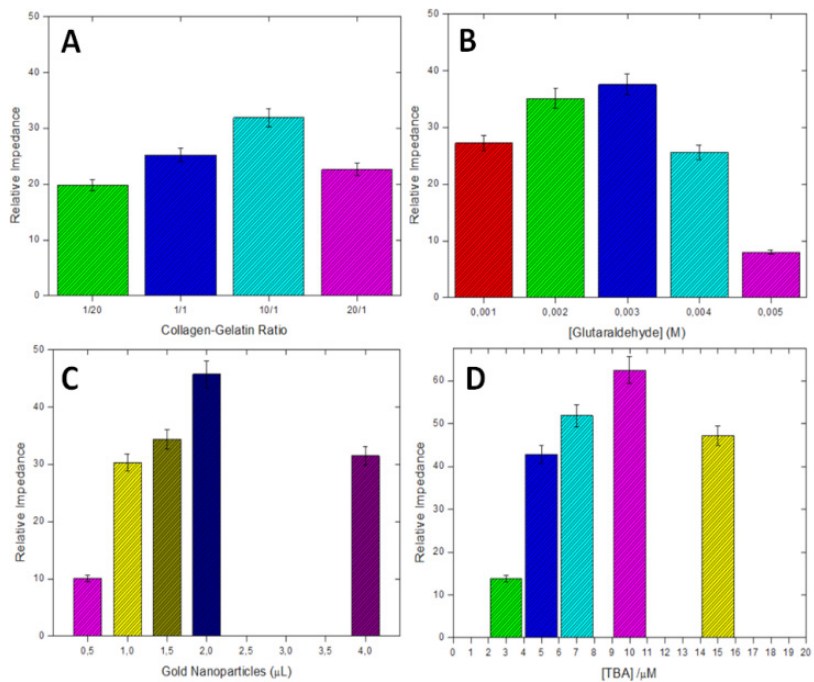

Figure 4. Effects of different parameters on apta-sensor performance: Collagen-gelatin ratio (A), glutaraldehyde concentration (B), AuNPs concentration (C) and TBA concentration (D). 


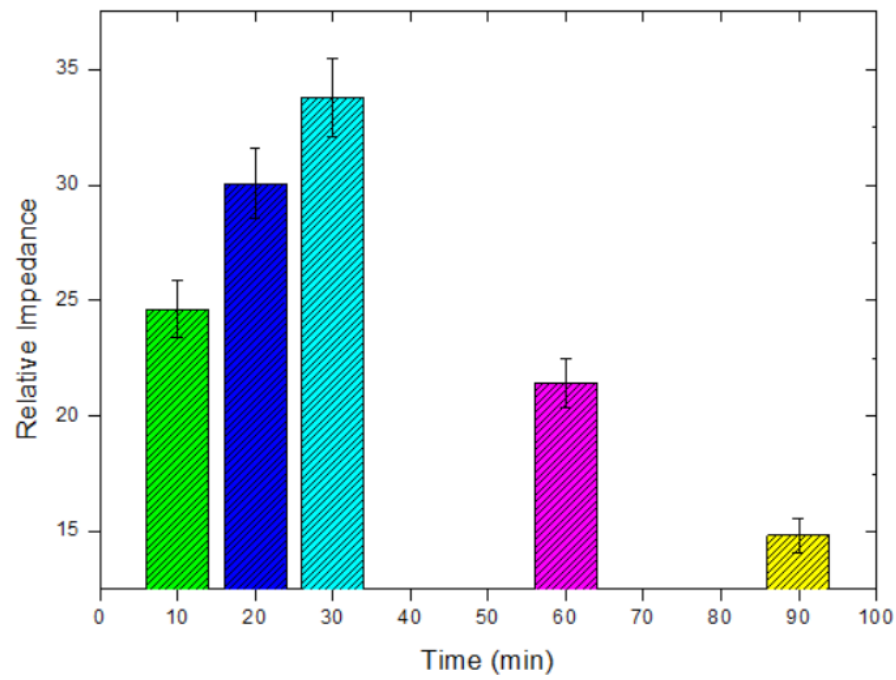

Figure 5. Effect of incubation time on apta-sensor performance.

inhibit the electron transfer due to the formation of extra resistance on the surface. Similarly, low TBA concentrations can not compensate for effective thrombin interaction, while very high amounts of thrombin still reduce the impedimetric response by blocking the pores of the biopolymeric structure. In addition, high TBA concentration can also lead to aptamer interactions and non-specific binding.
Another parameter essential in understanding sensor performance is the incubation time. For this purpose, equipotential electrodes were prepared and thrombin incubation was applied for a period of 10-90 min wherafter impedimetric measurements were performed. Optimal TBA incubation time was found to be $30 \mathrm{~min}$ (Figure 5).

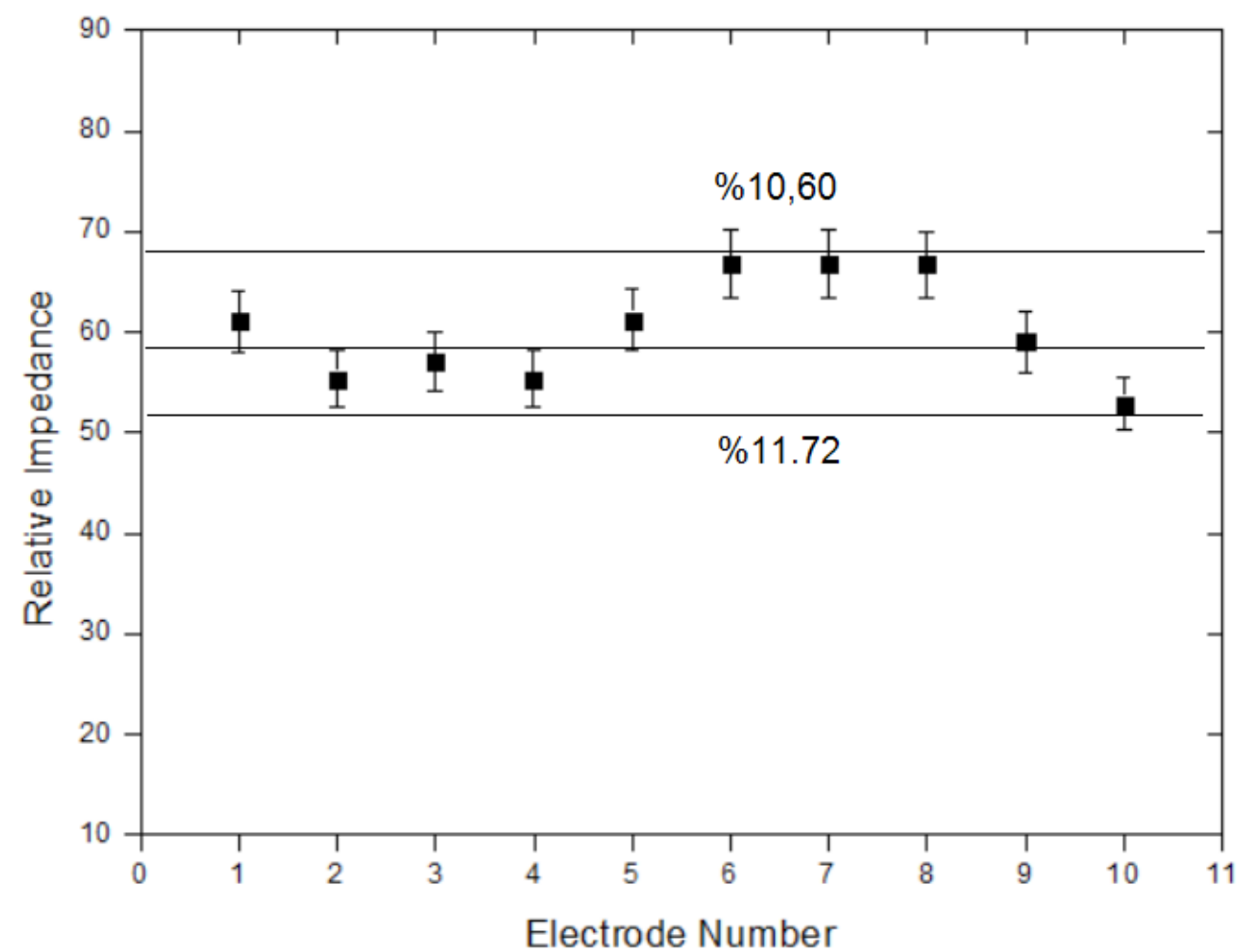

Figure 6. Reproducibility of collagen-gelatin-AuNPs-TBA electrode. 
As a result of the reproducibility study conducted for the validation of the apta-sensor, the thrombin apta-sensor seems to be reproducible (Figure 6). Deviations between the average value of the highest and lowest impedimetric responses were $10.60 \%$ and $11.72 \%$, respectively. Other data showed a deviation of less than $10 \%$.

Re-usability studies showed a decrease of $40 \%$ in the apta-sensor performance on the $14^{\text {th }}$ day (Figure 7). 10 day was the highest excepted period which showed a decrease of less than $30 \%$, an acceptable value.

Figure 8 shows the results of a calibration run in determining the range at which the apta-sensor can accurately measure the thrombin level. The apta-sensor showed two different calibration curves; a low concentration range (1.95-15.625 nM) and a high concentration range (15.25-1000 nM). The calibration curve equations for these two ranges were calculated as Relative Impedance (Low Concentration)
$=2.27 x$ [Trombin +9.40 and Relative Impedance $($ High Concentration $)=0.04 \times[$ Trombin $]+42.21$.

\section{CONCLUSION}

In this study, the development of a clinically usable, precise, simple and economical aptasensor for the determination of thrombin levels was aimed. Apta-sensors have gained importance in sensor technologies in recent years, especially after 2010, an extensive amount of studies have been the case especially for those dealing with the application of synthetic DNA chains as the biological sensitive component, are the basis of this work. The present results reveal the collagengelatin-AuNPs-TBA system to be a suitable sensor matrix for the accurate measurement of thrombin levels. The AuNPs in the system enhances both aptamer immobilization and electron transfer efficiency, enabling the thrombin detection to be performed at very low detection limits of $1.95 \mathrm{nM}$. The developed sensor system shows promise as

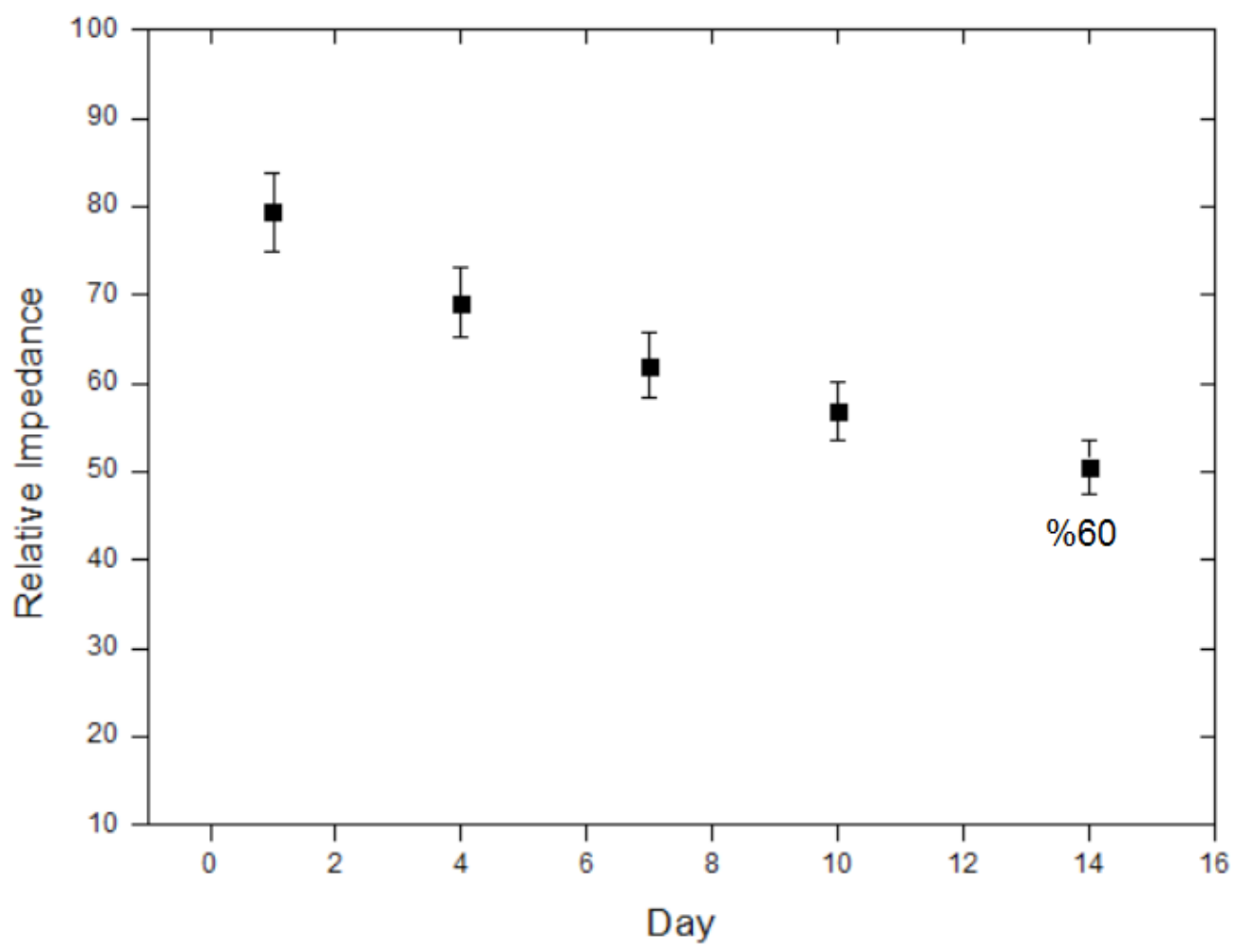

Figure 7. Reusability of collagen-gelatin-AuNPs-TBA electrode. 

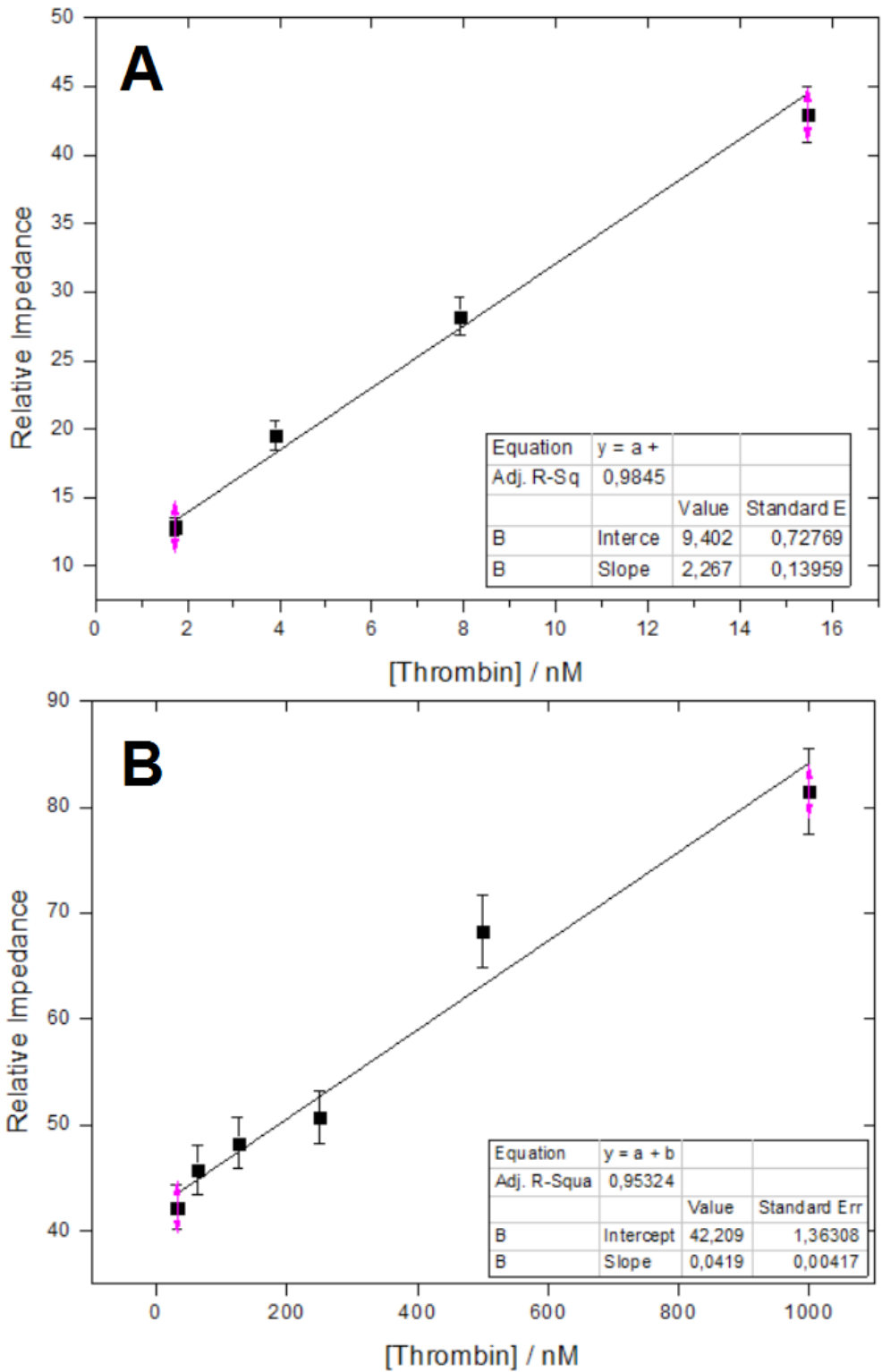

Figure 8. Calibration graph for low (A) and high (B) concentration ranges of the apta-sensor.

a practical, precise and economical system for application using biological fluids such as serum and plasma in the clinic.

\section{Acknowledgement}

This research was supported by Ankara University Scientific Research Projects Coordinator. Project No: 16B0430001.

References

1. P.R. Coulet, What is a Biosensor? Chapter 1, Biosensor principles and applications. New York, 1991, 1-6.

2. A.P.F. Turner, Biosensors: Fundamentals and Applications. Oxford University Press, 1987, 5-7.

3. E.A.H. Hall, Biosensors, Ch.1: Biosensors in context. Open University Press, England, 1990, 3-30.

4. L.B. McGown, M.J. Joseph, J.B. Pitner, G.P. Vonk, C.P. Linn, The nucleic acid ligand: A new tool for molecular recognition, Anal. Chem., 67 (1995) 663-668.

5. S.R. Mikkelsen, Electrochemical Biosensor for DNA sequence detection, Electroanalysis, 8 (1996) 15-19. 
6. K. Kerman, B. Meric, D. Ozkan, P. Kara, A. Erdem M. Ozsoz, Electrochemical DNA biosensor for the determination of Benzo[a]pyrene-DNA adducts, Anal. Chim. Acta, 450 (2001) 45-52.

7. J. Wang, G. Rivas, J.R. Fernandes, M. Jiang, J.L.L. Paz, R. Waymire, T.W. Nielsen, R.C. Getts, Adsorption and detection of DNA dendrimers at carbon electrodes. Electroanalysis, 10 (1998), 553-556.

8. E. Emregül, Development of a new biosensor for superoxide radicals, Anal. Bioanal. Chem., 383 (2005) 947-54.

9. E. Emregül, S. Sungur, U. Akbulut, Immobilization of glucose oxidase onto gelatin for biosensor construction, J. Biomat. Sci. Polym. E, 16 (2005) 505-519.

10. R. Malhotra, V. Patel, J.P. Vaqu, J.S. Gutkind, J.P. Rusling, Ultrasensitive Electrochemical immunosensor for oral cancer biomarker IL-6 using carbon nanotube forest electrodes and multilabel amplification, Anal. Chem., 82 (2010) 3118-3123.
11. M. Yang, C. Wang, Label-free immunosensor based on gold nanoparticle silver enhancement, Anal. Biochem., 385 (2009) 128-131.

12. B. Derkus, P. Acar-Bozkurt, M. Tulu, K.C. Emregul, C. Yucesan, E. Emregul, Simultaneous quantification of myelin basic protein and tau proteins in cerebrospinal fluid and serum of multiple sclerosis patients using nanoimmunosensor, Biosens. Bioelectron., 89 (2017) 781-788.

13. D. Davalos, K.M. Baeten, Early detection of thrombin activity in neuroinflammatory disease, Ann. Neurol., 75 (2014) 303-308.

14. J. Chapman, Thrombin in inflammatory brain diseases, Autoimmun. Rev., 5 (2006), 528-531.

15. B. Derkus, Y.E. Arslan, A.T. Bayrac, I. Kantarcioglu, K.C. Emregul, E. Emregul. Development of a novel aptasensor using jellyfish collagen as matrixand thrombin detection in blood samples obtained from patients withvarious neurodisease, Sens. Actuators B, 228 (2016) 725-736. 
